[Radiocarbon, Vol. 10, No. 2, 1968, P. 333-345]

\title{
RIKEN NATURAL RADIOCARBON MEASUREMENTS IV
}

\author{
FUMIO YAMASAKI, TATSUJI HAMADA, \\ and CHIKAKO FUJIYAMA \\ Institute of Physical and Chemical Research (RIKEN) \\ Komagome, Bunkyo-ku, Toyko, Japan
}

The $\mathrm{C}^{14}$ dates given below are a continuation of the work presented in our previous list (RIKEN III), and have been obtained by counting $\mathrm{CO}_{2}$ at ca. 2 atm pressure in a $2.7 \mathrm{~L}$ stainless steel counter. Results obtained mainly during 1967 are described.

Shell samples were treated with $1 \%$ HC1 to remove the outer $10 \%$. Calcareous deposits on the surface, when observed, were removed by mechanical means.

Dates were calculated on the basis of the $\mathrm{C}^{14}$ half-life of $5568 \mathrm{yr}$ and $95 \%$ NBS oxalic acid as modern standard. No correction was applied even for fresh water shell samples.

\section{SAMPLE DESGRIPTIONS}

I. GEOLOGIC SAMPLES

\section{A. Japan}

\section{Iide series}

Wood found at ca. $40 \mathrm{~m}$ from entrance of lateral pit dug into ancient landslide material, near Shirakawa dam at Iide-machi, Nishiokitama-gun, Yamagata pref. ( $38^{\circ} 0^{\prime} \mathrm{N}$ Lat, $139^{\circ} 55^{\prime} \mathrm{E}$ Long). Coll. by S. Akutagawa; subm. 1966 by K. Kojima, Public Works Research Inst.

\section{N-314. Iide 1}

$14,990 \pm 260$

\section{N-358. Iide 2}

$14,800 \pm 330$

Each sample is from different piece of wood. Comment (K.K.): dates are much older than expected age of landslide.

\section{Shiragake series}

Charred wood samples from Arasawa pumice flow at Shiragake, Nikko city, Tochigi pref. (36 $44^{\prime} \mathrm{N}$ Lat, $139^{\circ} 34^{\prime} \mathrm{E}$ Long). Coll. 1966 and subm. by M. Oishi, Natl. Research Center for Disaster Prevention. Comment (M.O.): dates Arasawa pumice flow.

\section{N-355-1. Shiragake 1}

N-355-2. Shiragake 2
$13,800 \pm 250$

11,850 в.C.

$13,500 \pm 240$

11,550 в.c. 
N-356. Matsushiro

$14,000 \pm 255$

12,050 B.C.

Carbonized grass from hot spring well, ca. $10 \mathrm{~m}$ deep, at Kagai, Matsushiro-machi, Nagano city, Nagano pref. $\left(\begin{array}{ll}36^{\circ} & 24^{\prime} \\ \mathrm{N} & \text { Lat, } 138^{\circ}\end{array}\right.$ 13' E Long). Material considered bog sediment at Matsushiro basin. Coll. 1966 and subm. by H. Takahashi, Natl. Research Center for Disaster Prevention. Comment (H.T.): dates latest period of lake formation at Matsushiro basin.

\section{Sasakawa series}

Wood and peat exposed from sea bed by Niigata Earthquake in 1964, off Sasakawa, Sanboku-mura, Iwafune-gun, Niigata pref. (38 $25^{\prime}$ $\mathrm{N}$ Lat, $139^{\circ} 20^{\prime}$ E Long). Coll. 1964 by Niigata Prefectural Fisheries Experimental Station; subm. by H. Takahashi.

\section{N-357-1. Wood}

N-357-2. Peat

\section{N-308. Inzai-machi}

Marine shell (Mactra sulcataria) from Omori, Inzai-machi, Inba-gun, Chiba pref. (35 $51^{\prime} \mathrm{N}$ Lat, $140^{\circ} 8^{\prime} \mathrm{E}$ Long). Shell layer, $3.4 \mathrm{~m}$ thick, is $1.6 \mathrm{~m}$ below ground surface, underlain by sand and clay. Coll. and subm. 1965 by M. Nishimura, Waseda Univ. Comment (M.N.): date gives information on valley formation of Tone R., where many prehistoric remains are found.

\section{N-309. Daisen}

A.D. 1040

$910 \pm 105$

Charred wood from Hijira, Yasugi city, Shimane pref. $\left(35^{\circ} 25^{\prime} \mathrm{N}\right.$ Lat, $133^{\circ} 11^{\prime} \mathrm{E}$ Long), from basaltic sand and clay, $1 \mathrm{~m}$ thick, above pumice bed of volcanoes, Mt. Daisen and Mt. Sambeyama. Coll. and subm. by T. Kimachi, Yonago Kita High School.

\section{Sarobetsu series}

Material from peat bed at Sarobetsu plain, Toyotomi-machi, Teshiogun, Hokkaido (45ㅇ $8^{\prime} \mathrm{N}$ Lat, $141^{\circ} 43^{\prime} \mathrm{E}$ Long). Coll. 1966 by H. Ando; subm. by M. Kurokawa, Hokkaido Development Bureau.

\section{N-276-1. Wood}

$$
\begin{array}{r}
1340 \pm 110 \\
\text { A.d. } 610 \\
1530 \pm 110 \\
\text { A.d. } 420
\end{array}
$$

N-276-2. Peat

Both samples are from base of peat bed, $2.2 \mathrm{~m}$ below surface. Comment (M.K.): dates are younger than previously expected: 3000 to $5000 \mathrm{yr}$ considering normally accepted value of peat deposition rate of $1 \mathrm{~cm} / 10 \mathrm{yr}$ in Hokkaido and later shrinkage of peat bed. 
N-324. Musashi Bank

$1950 \pm 110$

A.D. 0

Upper jaw bone of whale from sea bed at Musashi Bank, $\mathrm{N}$ Japan Sea (44 $50^{\prime} \mathrm{N}$ Lat, $141^{\circ} 18^{\prime} \mathrm{E}$ Long), $120 \mathrm{~m}$ deep, where Tertiary sedimentary rocks are exposed. Dredged by Umitaka-maru, training ship of Tokyo Univ. of Fisheries; subm. by S. Kuroda.

\section{N-360. Kozu Island}

$1950 \pm 110$

Carbonized wood from road to Tako Beach, Kozu Is., Izu Is., Tokyo city (34 $12^{\prime} \mathrm{N}$ Lat, $139^{\circ} 9^{\prime} \mathrm{E}$ Long), from volcanic ash $100 \mathrm{~m}$ above sea level. Coll. and subm. by S. Kuroda. Comment (S.K.): dates latest eruption period of Kozu Is. believed 11th or 12th century A.D.

\section{B. Australia}

\section{Echuca series}

Charcoal fragments from Goulburn valley, Victoria, Australia, which determine age of Quaternary tectonics, fluviatile sediments, and associated soils in Echuca area (Bowler and Harford, 1966; Bowler, 1967). Coll. and subm. 1966 by J. M. Bowler, Australian Natl. Univ.

\section{N-294. Echuca C3}

$215 \pm 105$

Plant root charcoal from gravel pit $10.5 \mathrm{~km} \mathrm{NE}$ of Rochester $\left(36^{\circ}\right.$ $17^{\prime} \mathrm{S}$ Lat, $144^{\circ} 47^{\prime} \mathrm{E}$ Long), $1.8 \mathrm{~m}$ below surface. Carbonaceous remains appeared truncated by undisturbed cross-bedding in overlying sand. Comment (J.M.B.): in view of recent age and mature soil profile developed on sand, material must be regarded as intrusive.

\section{N-295. Echuca C4}

$720 \pm 110$

Plant root charcoal from same site as $\mathrm{N}-294,2.7$ to $3.0 \mathrm{~m}$ below surface in gray calcareous plastic clay disconformably underlying channel sand of Campaspe prior stream on which well-organized red-brown earth soil has developed. Comment (J.M.B.): material is now regarded as intrusive from near present surface.

\section{N-296. Echuca C5}

$13,000 \pm 330$

Fragmental carbon from gravel pit $1 \mathrm{~km} \mathrm{~N}$ of McCoy's Bridge across Goulburn R. near Kotupna ( $36^{\circ} 9^{\prime} \mathrm{S}$ Lat, $145^{\circ} 8^{\prime} \mathrm{E}$ Long), $4.5 \mathrm{~m}$ below surface in coarse cross-bedded sand and gravel of ancestral river channel of Goulburn system incised into mottled clay.

\section{N-297. Echuca C6}

$$
5170 \pm 130
$$$$
3220 \text { B.c. }
$$

Framental carbon from same site as $\mathrm{N}-296,1.8$ to $2.7 \mathrm{~m}$ below surface in gray silt and sandy clay overlying ancestral river sand of N-296. 
N-298. Shepparton C1

$29,700 \pm 1250$

Fragmental carbon from $\mathrm{N}$ bank of Goulburn R., $8 \mathrm{~km} \mathrm{~S}$ of Shepparton (36 $27^{\circ} \mathrm{S}$ Lat, $145^{\circ} 22^{\prime} \mathrm{E}$ Long), $9 \mathrm{~m}$ below present ground surface in prior stream bed sand and gravel overlying leached and mottled clay and ferruginous sandstone.

\section{N-299. Shepparton 2a}

$\mathbf{2 5 , 5 0 0} \pm \mathbf{7 7 0}$ in a clay plug infilling final channel of prior stream dated by $\mathrm{N}-298$.

\section{N-300. Shepparton $2 b$}

$23,800 \pm 610$

Fragmental carbon from same site as N-299, $5.75 \mathrm{~m}$ below surface.

\section{N-301. Shepparton 3}

$16,150 \pm 330$

Fragmental carbon from section of $\mathrm{N}$ bank of Goulburn R., $8 \mathrm{~km}$ SSW of Shepparton (36 $27^{\prime} \mathrm{S}$ Lat, $145^{\circ} 21^{\prime}$ E Long), $2.7 \mathrm{~m}$ below surface of inset (Coonambidgal) terrace, in bedded river sand, disconformably overlying mottled clay and disconformably overlain by younger silt and sandy clay represented by N-303.

\section{N-302. Shepparton 4}

$4970 \pm 125$

3020 B.C.

Fragmental carbon from same stratigraphic section as N-298, 299, and $300,3.6 \mathrm{~m}$ below surface in fine clayey sand of inset (Coonambidgal) terrace incised into prior stream sediments represented by N-298, 299, and 300 .

\section{N-303. Shepparton 5}

$8090 \pm 155$

Charcoal of trees burnt in situ from same site as N-301, $3.0 \mathrm{~m}$ below surface in reddish brown silt with abundant oxidized earth, disconformably overlying channel sand of N-301 within inset (Coonambidgal) terrace of Goulburn $\mathbf{R}$.

\section{N-306. Barmah 1}

$20,300 \pm 450$

Carbonaceous plant fragments from gravel pit $1.5 \mathrm{~km} \mathrm{SE}$ of Barmah and $22 \mathrm{~km} \mathrm{NE}$ from Echuca ( $36^{\circ} 1^{\prime} \mathrm{S}$ Lat, $144^{\circ} 58^{\prime} \mathrm{E}$ Long), 2.7 to 3.6 $\mathrm{m}$ below surface in stream bed sand of prior stream-ancestral river of Goulburn R. system. This stream continued across Cadell Block where it joined Green Gully-ancestral to Murray R.

$275 \pm 100$

N-307. Kanyapella 15

A.D. 1675

Fragmental carbon from gravel fan on E side of Echuca Depression, $17 \mathrm{~km}$ ENE of Echuca $\left(36^{\circ} 6^{\prime} \mathrm{S}\right.$ Lat, $144^{\circ} 58^{\prime} \mathrm{E}$ Long), $1.5 \mathrm{~m}$ below 
surface on bar of channel sand associated with lagoon entering Echuca Depression. Comment (J.M.B.): recent age obtained indicates recurrent deposition by this system to present time.

\section{Ryan's Creek series}

Material from valley of Ryan's Creek, at junction of creek and tributary, New South Wales, Australia (35 $48^{\prime} \mathrm{S}$ Lat, $149^{\circ} 19^{\prime} \mathrm{E}$ Long). Coll. and subm. 1966 by C. Crook, Australian Natl. Univ.

\section{N-325. Ryan's Creek I (JC 14/1)}

$2300 \pm 115$

Charcoal fragments from river sediments, Good Good Pedolith, forming terrace, dissected by present stream, ca. $2 \mathrm{~m}$ below surface.

\section{N-326. Ryan's Creek 2 (JC 14/2)}

$3520 \pm 120$

Charcoal fragments from river sediments, Ryan's Creek Pedolith, underlying Good Good Pedolith represented by N-325.

\section{Great Britain}

\section{N-293. Cawood, Yorkshire}

$$
1710 \pm 110
$$

Wood from Stockbridge Experimental Farm, Cawood, Yorkshire, England (53 $49^{\prime} \mathrm{N}$ Lat, $1^{\circ} 9^{\prime} \mathrm{W}$ Long), from presumed fluvioglacial sand containing seeds, leaves, and twigs, 135 to $140 \mathrm{~cm}$ below surface, $3.2 \mathrm{~km} \mathrm{~S}$ of Escrick moraine and $2 \mathrm{~km} \mathrm{~S}$ of Wharfe R. near its junction with Ouse R. Coll. and subm. 1966 by B. Matthews, Soil Survey of England and Wales. Estimated age: 5000 yr or older.

\section{PEDOLOGIC SAMPLES}

Samples of humic soil in volcanic ash from various localities coll. by K. Kawai, Natl. Inst. Agricultural Sci., and dated to determine relationships among soil age, weathering of primary minerals in soil, and clay mineral composition of soil. Comment: dated on total organic carbon in soil.

\section{N-277. Kutchian}

$$
815 \pm 110
$$

Material from Kutchian-machi, Abuta-gun, Hokkaido $\left(42^{\circ} 55^{\prime} \mathrm{N}\right.$ Lat, $140^{\circ} 46^{\prime} \mathrm{E}$ Long), 0 to $22 \mathrm{~cm}$ below surface. Ash layer is 2 to 3 $\mathrm{m}$ thick, underlain by grayish clay $5 \mathrm{~cm}$ thick, silt, and fine sandy volcanic soil. Coll. 1965. Comment (K.K.): date unexpectedly young.

N-278. Miura

$3380 \pm 125$

1430 в.c.

Material from Hasse-machi, Miura city, Kanagawa pref. $\left(35^{\circ} 10^{\prime}\right.$ N Lat, $139^{\circ} 38^{\prime}$ E Long), 18 to $30 \mathrm{~cm}$ below surface. Coll. 1963. 


\section{N-279. Nishigoshi}

$1220 \pm 110$

Material from Kuroishi, Nishigoshi-mura, Kikuchi-gun, Kumamoto pref. (32 $59^{\prime} \mathrm{N}$ Lat, $130^{\circ} 54^{\prime} \mathrm{E}$ Long), 15 to $34 \mathrm{~cm}$ below surface. Coll. 1963.

\section{PALYNOLOGIC SAMPLES}

Samples of palynologic interest, peat, and other organic material in soil, coll. from various localities by J. Nakamura, Kochi Univ. (Nakamura and Tsukada, 1960; Nakamura, 1965). Comment: dated on total organic carbon in soil.

\section{Kumanoyu series}

Clayey peat deposited on ancient solfatara and containing volcanic ash, silt, pebbles, and wood fragments, more than $20 \mathrm{~m}$ thick, at Kumanoyu hot spring, Nanae-machi, Kameda-gun, Hokkaido $\left(41^{\circ} 56^{\prime} \mathrm{N}\right.$ Lat, $140^{\circ} 39^{\prime}$ E Long). Coll. 1965.

\section{N.340. Kumanoyu 1}

$14,200 \pm 260$

$70 \mathrm{~cm}$ below surface.

\section{N-341. Kumanoyu 2}

$14,800 \pm 260$

$100 \mathrm{~cm}$ below surface.

\section{2,850 в.C.}

\section{N-342. Kumanoyu 3}

$15,700 \pm 290$

$240 \mathrm{~cm}$ below surface.

\section{N-343. Chippubetsu}

$23,300 \pm 910$ Long), 8.2 to $8.3 \mathrm{~m}$ below surface. Coll. 1965 .

\section{N-344. Itachino}

$4490 \pm 140$

2540 B.c.

Humic soil from sediments of lacustrine origin, $6.3 \mathrm{~m}$ thick, at Itachino, Nangoku city, Kochi pref. (33 $33^{\prime} \mathrm{N}$ Lat, $133^{\circ} 34^{\prime} \mathrm{E}$ Long), 135 to $150 \mathrm{~cm}$ below surface. Coll. 1966.

\section{ARCHAEOLOGIC SAMPLES}

\section{A. Japan}

\section{N-286. Nishinojo}

$5460 \pm 130$

Carbon in pottery matrix of potsherd from Nishinojo shell mound, Namiki, Kozaki-machi, Katori-gun, Chiba pref. (35 $53^{\circ}$ N Lat, $140^{\circ} 23^{\prime}$ E Long), found in dark soil 30 to $50 \mathrm{~cm}$ thick containing shell. Pottery 
considered comparable with Early Jomon, Hanazumi-kaso type, or Earliest Jomon, Kayama type (Nishimura et al., 1955; Nishimura, 1965). Coll. 1963 and subm. 1966 by M. Nishimura, Waseda Univ. Comment: shell and charcoal from same shell mound yielded $8150 \pm 180$ and $8240 \pm 190$ (N-168, 170, RIKEN II), respectively.

\section{N-287. Shimogumi}

$6030 \pm 135$

Carbon in pottery matrix of potsherd from Shimogumi shell mound, Shimodamachi, Kohoku-ku, Yokohama city, Kanagawa pref. (35 $34^{\prime} \mathrm{N}$ Lat, $139^{\circ} 37^{\prime}$ E Long), found in shell layer 80 to $100 \mathrm{~cm}$ thick overlain by surface soil 30 to $40 \mathrm{~cm}$ thick. Pottery is of Early Jomon, Hanazumikaso type (Nishimura and Nakazawa, 1950). Coll. 1949 and subm. 1966 by M. Nishimura.

\section{N-288. Hataya-araku}

$4840 \pm 140$

2890 B.c.

Carbon in pottery matrix of potsherd from Hataya-araku shell mound, Neto, Kashiwa city, Chiba pref. ( $35^{\circ} 53^{\prime} \mathrm{N}$ Lat, $140^{\circ} 0^{\prime} \mathrm{E}$ Long), found in shell layer $50 \mathrm{~cm}$ below ground surface. Pottery is of unnamed type considered to belong to Early Jomon. Coll. 1956 and subm. 1966 by M. Nishimura.

\section{N-289. Ta}

$4960 \pm 125$

Carbon in pottery matrix of potsherd from $\mathrm{Ta}$ shell mound, Towada-mura, Tsukuba-gun, Ibaraki pref. $\left(36^{\circ} 0^{\prime} \mathrm{N}\right.$ Lat, $140^{\circ} 2^{\prime} \mathrm{E}$ Long), found in shell layer 40 to $50 \mathrm{~cm}$ thick. Pottery is of Early Jomon, Sekiyama type. Comment: fresh water and marine shell samples from same shell mound yielded $5640 \pm 150$ and $5630 \pm 140$ (N-191-1 and N-191-2, RIKEN III). Coll. and subm. 1966 by M. Nishimura.

\section{Mukoyama shell mound series}

Material from Mukoyama shell mound, Toride-machi, Kita-somagun, Ibaraki pref. ( $35^{\circ} 56^{\prime} \mathrm{N}$ Lat, $140^{\circ} 1^{\prime}$ E Long). Shell layer is between dark soil overlying loam, 80 to $90 \mathrm{~cm}$ thick, overlain by surface soil 30 $\mathrm{cm}$ thick, and assoc. with Early Jomon pottery of Ukishima III type. Coll. 1966 and subm. by M. Nishimura.

N-365. Charcoal

Charcoal fragment found on floor of dwelling pit.

N-366-1. Marine shell (Meretrix lusoria)

N-366-2. Fresh water shell (Corbicula japonica)

Both shell samples are from E side of Trench C.
$4920 \pm 195$

2970 B.c.

$5090 \pm 130$

3140 B.c.

$5090 \pm 140$

3140 в.c. 


\section{Shin shell mound series}

Material from Shin shell mound, Takeda, Kozaki-machi, Katori-gun, Chiba pref. ( $35^{\circ} 52^{\prime} \mathrm{N}$ Lat, $140^{\circ} 25^{\prime} \mathrm{E}$ Long). Shell layer, 30 to $40 \mathrm{~cm}$ thick, is on dark soil and assoc. with Late Jomon pottery of Angyo I and II types. Coll. 1966 and subm. by M. Nishimura.

\section{N-367-1. Marine shell (Meretrix lusoria)}

$3170 \pm 120$

\section{N-367-2. Fresh water shell (Corbicula japonica)}

1220 B.c.

Both samples are from $\mathrm{N}$ side of Trench $\mathrm{E}$.

\section{Dochi shell mound series}

Material from Dochi shell mound, S bank of Kokai R., Moriya-cho, Tsukuba-gun, Ibaraki pref. ( $35^{\circ} 57^{\prime} \mathrm{N}$ Lat, $140^{\circ} 1^{\prime} \mathrm{E}$ Long). Two shell layers are distinguishable 20 to $30 \mathrm{~cm}$ below ground surface: upper one, $20 \mathrm{~cm}$ thick, containing fresh water shell (Corbicula japonica) and assoc. with fiber tempered pottery of Early Jomon period, and lower one, 30 to $40 \mathrm{~cm}$ thick, on dark soil containing marine shell (Anadara sp., Meretrix sp., and Ostrea sp.) and assoc. with pottery of Earliest Jomon, Kayama type. Coll. and subm. 1967 by M. Nishimura.

\section{N-368. Marine shell (Anadara granosa bisenensis)}

\section{Fresh water shell (Corbicula japonica) 3310 B.c.}

To study geomorphological development of area, peat and shell samples are coll. from reconstruction site of Joso bridge across Kokai R. near Dochi shell mound ( $35^{\circ} 58^{\prime} \mathrm{N}$ Lat, $140^{\circ} 1^{\prime} \mathrm{E}$ Long) and dated.

\section{N-370. Peat}

From alluvial deposit overlying marine sand.

N-371. Marine shell (Anadara subcrenata)

From marine sand, about $10 \mathrm{~m}$ below alluvial deposit.
$2780 \pm 120$

830 B.C.

\section{Hazama shell mound series}

Material from Hazama shell mound, Itako-machi, Namegata-gun, Ibaraki pref. ( $35^{\circ} 57^{\prime} \mathrm{N}$ Lat, $140^{\circ} 33^{\prime}$ E Long). Shell layer, $30 \mathrm{~cm}$ thick, is on dark soil overlain by surface soil 20 to $30 \mathrm{~cm}$ thick. Associated pottery is of Earliest Jomon period, Ugashimadai type. Coll. and subm. 1967 by M. Nishimura.

\section{N-372. Carbon in pottery matrix}




\section{N-373. Marine shell (Meretrix lusoria)}

$$
6910 \pm 145
$$

\section{N-374. Daishuku}

$3940 \pm 125$

Toride-machi, Kita-soma-gun, Tonic). Shell, Kita-somagun, Ibaraki pref. (350 $54^{\circ} \mathrm{N}$ Lat, $140^{\circ} 4^{\prime} \mathrm{F}$ Long). Shell layer, 30 to $40 \mathrm{~cm}$ thick, is overlain by surface soil 20 to $30 \mathrm{~cm}$ thick, and assoc. with Middle Jomon pottery of Kasori E type. Coll. and subm. 1967 by M. Nishimura.

\section{N-375. Minami-sakai}

$3960 \pm 125$

Marine shell (Meretrix lusoria) from Minami-sakai shell mound, Kita-sakaikubo, Inai-machi, Ishinomaki city, Miyagi pref. $\left(38^{\circ} 27^{\prime} \mathrm{N}\right.$ Lat, $141^{\circ} 22^{\prime}$ E Long). Shell layer, 30 to $40 \mathrm{~cm}$ thick, is ca. $30 \mathrm{~cm}$ below ground surface. Associated pottery considered comparable with Late Jomon, Horinouchi type in Kanto District. Coll. 1966 by H. Kaneko, Waseda Univ.; subm. by M. Nishimura.

\section{N-280. Honancho}

$1410 \pm 110$

Charred timber from Dwelling Pit $\mathrm{F}$ of Yayoi period at Honan-cho,

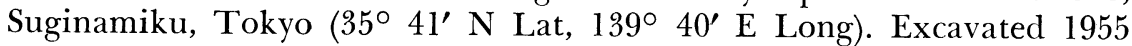
by M. Sakakibara and A. Aoki. Pottery is Maenocho type. Coll. 1955 and subm. 1958 by N. Watanabe. Comment (N.W.): $1220 \pm 130$ (N-57, RIKEN I) associated with same type pottery.

\section{Todoroki series}

Charcoal and shell from Todoroki shell mound of Jomon period at Miyanosho, Udo city, Kumamoto pref. (32 $41^{\prime} \mathrm{N}$ Lat, $130^{\circ} 38^{\prime} \mathrm{E}$ Long), excavated 1966 by T. Esaka, Keio Univ. Coll. and subm. 1966 by N. Watanabe.

\section{N-317. Charcoal}

$$
\begin{aligned}
& 3960 \pm 175 \\
& 2010 \text { B.c. }
\end{aligned}
$$

\section{N-318. Shell (Ostrea sp.)}

$3960 \pm 130$

Materials were from same shell layer of Loc. 23, associated with Ataka-type pottery of Middle Jomon period.

\section{N-319. Charcoal}

$3370 \pm 135$

\section{N-320. Shell (Meretrix sp.)}

Materials were from same shell layer of Loc. ET2, associated with Kitakuneyama-type pottery of Late Jomon period. 


\section{Kitami series}

Charcoal from dwelling pit of Middle Jomon period under refuse deposit at Kitami-cho, Setagaya-ku, Tokyo $\left(35^{\circ} 38^{\prime} \mathrm{N}\right.$ Lat, $139^{\circ} 36^{\prime} \mathrm{E}$ Long), excavated 1948 by N. Watanabe and $\mathrm{H}$. Watanabe, Univ. of Tokyo. Pottery is Kasori E II type. Coll. 1948 and subm. 1966 by N. Watanabe.

\section{N-321. Charcoal on floor of dwelling pit}

\section{N-322. Charcoal from deposit in dwelling pit}

Comment (N.W.): comparable dates $4513 \pm 300$ and $4546 \pm 220$ (C-603 and 548, Chicago II).

\section{B. Korea}

\section{Hwano-li series}

Wooden part of saddle from ancient tomb No. 34 at Hwano-li, Kyungju city, Korea ( $35^{\circ} 51^{\prime} \mathrm{N}$ Lat, $129^{\circ} 12^{\prime} \mathrm{E}$ Long). Expected age: 5 th or 6 th century A.D. Coll. 1965 by Y. J. Yun; subm. by Y. H. Kang, Kyungpuk Univ.

\section{N-351. Hwano-li 1}

$$
\begin{array}{rl}
1630 & \pm 110 \\
\text { A.d. } 320 & 1580 \\
1580 \\
\text { A.d. } 370
\end{array}
$$

N-352. Hwano-li 2

\section{Buyo series}

Charred rice and soybean grains beneath ground surface at Buyo city, Jungchungpuk-do, Korea $\left(36^{\circ} 16^{\prime} \mathrm{N}\right.$ Lat, $126^{\circ} 55^{\prime} \mathrm{E}$ Long). According to legend, they are provisions of Pèkché, which were burned during war in A.D. 660 against Silla. Coll. and subm. 1967 by Y. H. Kang.

N-353. Charred rice grains

\section{N-354. Charred soybean grains}

C. Africa
A.D. 1520

$$
430 \pm 105
$$

$$
520 \pm 105
$$

A.D. 1430

$$
435 \pm 105
$$

\section{N-290. Ngungani, Kenya (NG 66, Mound I)}

A.D. 1515

Charcoal from fill of large pit beneath low mound, ca. $60 \mathrm{~cm}$ below original ground level, at Ngungani, Chyulu Hills, Kenya $\left(2^{\circ} 35^{\prime} \mathrm{S}\right.$ Lat, $37^{\circ} 50^{\prime}$ E Long). Coll. 1966 by R. C. Soper; subm. by H. N. Chittick, Brit. Inst. Hist. and Archaeol. E. Africa.

\section{Kwale series}

Charcoal from remains of Early Iron age at Kwale, Kenya $\left(4^{\circ} 12^{\prime}\right.$ S Lat, $39^{\circ} 26^{\prime}$ E Long). Coll. 1966 by R. C. Soper; subm. by H. N. Chittick. 
N-291. Kwale 1 ( KW $66 \mathrm{~J} / 3$ )

Ca. $50 \mathrm{~cm}$ below present surface.

N-292. Kwale 2 (KW 66 A)

Ca. $30 \mathrm{~cm}$ below present surface. Comment (H.N.C.): N-292 required as check for $\mathrm{N}$-291, which could conceivably be more recent root intrusion carbonized in situ.

\section{Manda series}

Charcoal from site of Islamic settlement at Manda, Kenya $\left(2^{\circ} 13^{\prime}\right.$ $S$ Lat, $40^{\circ} 58^{\prime}$ E Long). Coll. and subm. 1966 by H. N. Chittick.

\section{N-338. Manda 1 (LP I (4))}

$$
1130 \pm 110
$$

From upper burnt level at top of strata of Period I.

\section{N-339. Manda 2 (LP V(5))}

\section{A.D. 820}

From lower part of strata of Period I overlying old beach. Comment (H.N.C.): true dates of both samples, based on assoc. Chinese porcelain and Islamic wares, are in 9 th and 10th centuries, probably between 850 and 950 A.D. N-338 is at end of period, perhaps early 10th century. N-339 is unlikely to date more than 50 yr before N-338 (Chittick, 1967).

\section{N-347. Bombo, Tanzania}

$$
1730 \pm 115
$$

Charcoal from Bombo, South Pare Hills, Tanzania $\left(4^{\circ} 16^{\prime} \mathrm{S}\right.$ Lat, $38^{\circ}$ $0^{\prime} \mathrm{E}$ Long), $2 \mathrm{~m}$ below surface, associated with Iron-age pottery. Coll. 1967 by R. C. Soper; subm. by H. N. Chittick. Comment (R.C.S.): pottery very similar to that of $\mathrm{K}$ wale (N-291 and 292, this list).

\section{N-348. Bombo Mission, Tanzania}

$$
1060 \pm 110
$$

Charcoal from Bombo Mission, South Pare Hills, Tanzania $\left(4^{\circ} 16^{\prime}\right.$ $S$ Lat, $38^{\circ} 0^{\prime}$ E Long), 70 to $80 \mathrm{~cm}$ below surface in hill-side rubbishtip of Iron-age date. Coll. and subm. 1967 by R. C. Soper. Comment (R.C.S.): sample belongs to different Iron-age culture from that of N-347. According to stylistic sequence of pottery, date was expected to be significantly later than that of N-257 at Gonja Maore $(1080 \pm 110$, RIKEN III).

\section{N-349. Amboni Cave, Tanzania (AM 67 (6))}

$$
1590 \pm 120
$$

Charcoal from Iron-age occupation layer, 52 to $58 \mathrm{~cm}$ below surface, in mouth of Amboni Cave, near Tanga, Tanzania (5 $5^{\circ} 4^{\prime} \mathrm{S}$ Lat, $39^{\circ} 3^{\prime}$ E Long). Coll. and subm. 1967 by R. C. Soper. Comment (R.C.S.): date 
is much earlier than expected, as associated pottery seemed unlikely to be earlier than ca. 12th or 13th century A.D.

N-346. Univ. of Ife Campus, Nigeria

$2300 \pm 115$

350 в.c.

Charcoal from Univ. of Ife campus, Ile-Ife, W. Nigeria $\left(7^{\circ} 31^{\prime} \mathrm{N}\right.$ Lat, $4^{\circ} 32^{\prime} \mathrm{E}$ Long). Sample contained in stone line separating 2 Holocene slope deposits, $80 \mathrm{~cm}$ below surface, and associated with undefined pottery and microliths. Coll. 1966 and subm. by H. Fölster, Univ. of Ife.

\section{Andes}

\section{N-310. Guillermo's House (TAM 1)}

$575 \pm 105$

Charcoal and burnt palm kernels from top 4 levels of Trench A at Guillermo's House, Peru ( $8^{\circ} 51^{\prime} \mathrm{S}$ Lat, $74^{\circ} 18^{\prime} \mathrm{W}$ Long). All levels are in very rich midden of Caimito complex. Coll. 1964 by D. W. Lathrap, Univ. of Illinois; subm. 1966 by S. Izumi, Univ. of Tokyo. Comment (D.W.L.): dates Caimito occupation at Imaríacocha. Expected age between A.D. 1200 to 1600 . Another measurement on Caimito complex: $630 \pm 60(\mathrm{Y}-1544)$.

\section{N-311. Ticuna Plaza (AMA 2)}

$1150 \pm 110$

Charcoal from large pit cut into sterile base, encountered in trench excavated in NW corner of Ticuna Plaza in Ticuna, Cashillococha, Peru ( $4^{\circ} 0^{\prime} \mathrm{S}$ Lat, $70^{\circ} 40^{\prime} \mathrm{W}$ Long). Pit was packed with ceramics of Nataq ceramic complex, sherd tempered, with red-on-cream rectilinear painting. Coll. 1964 by D. W. Lathrap; subm. 1966 by S. Izumi.

\section{N.312. Nueva Esperanza (UCA 17)}

$1180 \pm 105$

Charcoal from lower levels of pure midden of Nueva Esperanza complex, Nueva Esperanza, Peru $\left(8^{\circ} 14^{\prime} \mathrm{S}\right.$ Lat, $74^{\circ} 41^{\prime} \mathrm{W}$ Long). Coll. 1964 by T. P. Myers, Univ. of Illinois; subm. by S. Izumi. Comment (D.W.L.): material is probably earlier than Cumancaya material (1140 \pm 80, Y-1545) on seriational grounds.

\section{N-313. José's Hill (UCA 34)}

$$
1860 \pm 110
$$

Burnt shell of charapu turtle from Yarinacocha complex midden, José's Hill, Peru ( $8^{\circ} 15^{\prime} \mathrm{S}$ Lat, $74^{\circ} 39^{\prime} \mathrm{W}$ Long). Coll. 1964 by T. P. Myers; subm. 1966 by S. Izumi. Comment (D.W.L.): midden here overlay midden of Shakimu complex materials $(2600 \pm 100$, Y-1543), and should post-date them by considerable period of time.

\section{E. Great Britain}

\section{Burghead Fort series}

Charred oak (id. by J. S. Murray, Univ. of Aberdeen) from wall of Fort Burghead, Scotland (57 $42^{\prime} \mathrm{N}$ Lat, $3^{\circ} 30^{\prime} \mathrm{W}$ Long). No artifacts 
found inside fortress. Coll. and subm. 1966 by A. Small, Univ. of Aberdeen.

\section{N-327. Burghead Fort 1 (RS.1)}

$1560 \pm 110$

\section{N-328. Burghead Fort 2 (RS.2)}

\section{N-329. Burghead Fort 3 (RS.3)}

$1340 \pm 105$

A.D. 610

$1560 \pm 115$

REFERENCES

Date lists:

$\begin{array}{ll}\text { Chicago II } & \text { Libby, 1951 } \\ \text { RIKEN I } & \text { Yamasaki, Hamada, and Fujiyama, 1964 } \\ \text { RIKEN II } & \text { Yamasaki, Hamada, and Fujiyama, 1966 } \\ \text { RIKEN III } & \text { Yamasaki, Hamada, and Fujiyama, 1967 }\end{array}$

RIKEN III Yamasaki, Hamada, and Fujiyama, 1967

Bowler, J. M., 1967, Quaternary chronology of Goulburn Valley sediments and their correlation in southeastern Australia: Geol. Soc. Australia Jour., v. 14, pt. 2, p. 287-292.

Bowler, J. M. and Harford, L. B., 1966, Quaternary tectonics and the evolution of the Riverine Plain near Echuca, Victoria: Geol. Soc. Australia Jour., v. 13 p. $339-354$.

Chittick, H. N., 1967, Discoveries in the Lamu Archipelago: Azania II, p. 37-67.

Nakamura, J., 1965, Palynological study of the vegetational history since the Lateglacial period of the Lowland in Kochi Prefecture: Quaternary Research, v. 4, nos. $3-4$.

Nakamura, J. and Tsukada, M., 1960, Palynological aspects of the Quaternary in Hokkaido I, (1) The Oshima Peninsula: Res. Rep. Kochi Univ., v. 9, no. 10.

Nishimura, M., 1965, Shell-Mound of Nishinojo, Kozaki Town, Chiba Prefecture: Kodai, nos. 45-46.

Nishimura, M., Kaneko, H., Serizawa, C., and Esaka, T., 1955, Shell-Mound of Nishinojo, Chiba Prefecture: The Stone Age, no. 2.

Nishimura, M. and Nakazawa, T., 1950, Western Shell-Mound of Shimogumi, Shimoda, Kohoku-ku, Yokohama, Kanagawa Prefecture: Kodai, nos. 1-2. 